\title{
CARACTERIZACIÓN DE LAS \\ EMPRESAS COMERCIALIZADORAS DE \\ INSUMOS PARA TATUAJES EN LA CIUDAD \\ DE BOGOTÁ, LOCALIDAD DE SAN \\ CRISTÓBAL DEL BARRIO 20 DE JULIO
}

Martha Sofía Naranjo Parra

Laura Villamor Cárdenas

Facultad de Ciencias Administrativas,

Fundación Universitaria San Mateo.

\section{Resumen}

En el presente proyecto se realizará una caracterización de las empresas comercializadoras de insumos para tatuajes en la ciudad de Bogotá, específicamente, en la localidad de San Cristóbal del barrio 20 de julio. Teniendo en cuenta la oferta y la demanda en los últimos cinco años se espera identificar la calidad de los productos nacionales e internacionales, precios de las tiendas online y precios de las tiendas físicas y la variabilidad del mercado.

Teniendo en cuenta la necesidad del cliente, se realizará una muestra donde se obtengan resultados. De los estudios de tatuajes del barrio 20 de julio, los cuales son 15 estudios de tatuajes.

\section{Objetivos de investigación}

\section{Objetivo General}

Realizar una caracterización de las empresas comercializadoras de insumos para tatuajes en la ciudad de Bogotá, en la localidad San Cristóbal, barrio 20 de julio a partir del año 2013 al 2018.

\section{Objetivos Específicos}

- Identificar los estudios que comercializan insumos para tatuajes en el sector del 20 de julio.

- Establecer los sistemas de la oferta y la demanda de los insumos para tatuajes a nivel de competitividad.

- Diagnosticar las características adecuadas de calidad que deben tener los insumos de tatuajes según la normatividad para ser comercializados. 


\section{Justificación}

El propósito de este proyecto es identificar las características de calidad, precio y variabilidad del mercado, según la oferta y la demanda del mercado de los insumos para tatuajes en la localidad de San Cristóbal, barrio 20 de julio.

Se busca establecer la viabilidad de comercialización de insumos de tatuajes nacionales e internacionales, a través de una caracterización que indique resultados cuantitativos y cualitativos.

\section{Metodología}

Mixta (cuantitativa y cualitativa), se realizará un análisis descriptivo con un modo exploratorio en campo, donde se utilizarán una herramienta de observación instrumental.

Las técnicas de recolección de datos serán:

- Encuestas

- Entrevistas

- Focus grup

\section{Marco teórico}

De acuerdo con lo que se quiere mostrar en la investigación, se asocian unos temas de interés general que abarcan diversos aspectos en cuanto a la cultura de los tatuajes.

El enfoque que ha tenido este trabajo es cualitativo, ya que en él podemos conocer los inicios de la cultura del tatuaje, de dónde nace y sus principales expositores.

La palabra tatuaje, de origen polinesio, fue introducida en Europa por el explorador inglés James Cook en 1774 en la forma de tattaw. La historia dice que, prácticamente desde sus orígenes, la humanidad ha recurrido a técnicas como la del tatuaje, por lo menos ya desde la era neolítica (Josep, pág. 35). Se puede analizar que los polinesios fueron los principales expositores y los inicios de los tatuajes; ellos conformaban una religión y según ellos los tatuajes le daba jerarquía y respeto por esta razón se empezaban a tatuar desde muy jóvenes, esto daba a entender que pasaban de ser adolescentes a ser adultos.

Así mismo, los hombres y mujeres de la etnia ainu de Japón se tatuaban alrededor de la boca. Mientras que los tatuajes faciales con líneas curvas y espirales de la población de Nueva Zelanda son bien conocidos; en Samoa, en cambio, la cara no se tatúa, pero sí el vientre, el pecho y las piernas en los hombres, y los brazos y las piernas en las mujeres. (Josep, 2015, pág. 34). Los primeros tatuajes se realizaban en ciertas partes del cuerpo dependiendo el género y de su cultura ainu, una tribu indígena ubicada al norte de Japón, en las mujeres se implementaba los tatuajes en la boca y según su tamaño se podía identificar la edad en que ya se podía casar.

Entre las diversas técnicas utilizadas para el tatuaje hay que mencionar la punción y la sutura. En el primer caso, se efectúan pinchazos pequeños y poco profundos en la piel mediante un instrumento de corte o un punzón (Josep, 2015, pág. 40). En la actualidad existe Dotwork o puntillismo que consiste en realizar pequeños puntos y dándoles for- 
mas y tonalidades por lo general se utilizan colores grises y negros. En la actualidad la implementación de tatuajes tanto en Colombia y el resto del mundo se está volviendo viral, las prácticas corporales relacionadas con el tatuaje han estado presentes en todo el mundo y sigue prácticas de tipo estético, religioso y social que en casos extremos termina siendo impregnada por el mercado.

La venta de insumos para tatuajes comenzó en Bogotá gracias "Danny Tattoo", un belga que introdujo la práctica hasta volverse popular en el país a comienzos de los años 90. Ese fue el comienzo de la expansión de este negocio a nivel nacional, un país en el que esta cultura "subterráneo" tuvo que sortear un sin número de desafíos para poder posicionarse y ganar respeto" (Dinero, 2017).

Por lo anteriormente expuesto, concluimos que aproximadamente la venta de insumos a Colombia llego hace 25 años. Siendo un comercio no muy conocido que en los últimos años ha tomado fuerza.

Es el panorama expuesto, el llamado más vehemente para que las empresas gestionen procesos de fortalecimiento con el objetivo de adaptarse a los numerosos cambios que está afrontando el mercado actualmente.

\section{Bibliografía}

Hernández Sampieri, R. (2010). Metodología de la investigación. En R. Hernández Sampieri, Metodología de la investigación (págs. 79-82). México: Mc Graw Hill . Recuperado el 25 de Agosto de 2018, de https://campusvirtual.univalle.edu.co/moodle/pluginfile.php/1184249/ mod_resource/content/1/Sampieri\%20y\%20Baptista\%205ta\%20Edicion.pdf Josep, M. (2015). La cultura del cuerpo. Barcelona: Editorial UOC. Recuperado el 26 de Septiembre de 2018, de ProQuest Ebook Central, https://ebookcentral.proquest.com/lib/ bibliofussp/detail.action?doclD=5349909.

DINERO. (22 de Noviembre de 2017). Dinero. Obtenido de https://www.dinero.com/emprendimiento/articulo/estudios-de-tatuajes-en-colombia/252585 